\title{
OPEN ACCESS DAN UNBUNDLING DALAM TATA KELOLA GAS BUMI INDONESIA DITINJAU DARI PERSPEKTIF EKONOMI KERAKYATAN
}

\author{
Nuzul Rahmayani \\ Fakultas Hukum Universitas Muhammadiyah Sumatera Barat \\ Jln. By Pass Aur Kuning Kota Bukittinggi, Sumatera Barat
}

\begin{abstract}
ABSTRAK
$\mathrm{G}$ as alam merupakan komoditas strategis yang menguasai hajat hidup orang banyak, dan termasuk pada sumber daya alam yang tidak dapat diperbaharui. Oleh sebab itu, tata kelola gas bumi harus sangat dilakukan dengan hati-hati sesuai dengan amanat UUD 1945 khususnya Pasal 33 ayat (2) dan (3). Namun, UU Nomor 22 Tahun 2001 tentang Migas dan ketentuan dibawahnya terdapat inkonsistensi dalam mengatur tentang skema pemanfaatan umum dalam tata kelola gas bumi. Inkonsistensi antar peraturan perundangundangan ini tentu saja berimbas pada upaya pemanfaatan sumber daya alam untuk tujuan "sebesar-besarnya kemakmuran rakyat". Konsep open access yang otomatis diikuti oleh unbundling terbukti telah memperpanjang mata rantai usaha pada sektor hilir gas bumi dan berdampak pada tingginya harga jual gas bumi.
\end{abstract}

Kata Kunci: open access, unbundling, gas bumi

\section{LATAR BELAKANG}

Indonesia merupakan Negara yang dianugerahi oleh Allah SWT potensi sumber daya alam yang luar biasa. Salah satu potensi sumber daya alam itu adalah gas bumi, yang merupakan potensi energi yang sangat strategis untuk keberlangsungan hajat hidup manusia. Gas bumi diklaim merupakan salah satu sumber energi yang paling bersih karena memiliki intensitas karbon rendah dan paling aman, serta berkontribusi sekitar 23\% sebagai sumber energi primer dunia. Terkait dengan Indonesia sebagai salah satu produsen gas alam, menurut data BP Statistical Review of World Energy 2015, Indonesia merupakan Negara yang memiliki cadangan gas terbesar ketiga di Wilayah Asia Pasifik, dan berkontribusi untuk 1,5\% dari total gas dunia. Selain itu, Indonesia juga merupakan produsen gas bumi terbesar ke-10 dunia pada tahun 2014 , yaitu 73,4 milyar m.1 Bahkan, berdasarkan Data BP Statistics 2014, cadangan gas bumi terbukti Indonesia mencapai 103,3 triliun kaki kubik dan menempatkan Indonesia berada pada posisi ke-14 pemilik cadangan terbesar di dunia. ${ }^{2}$

Berdasarkan data tersebut, maka secara umum dapat disimpulkan bahwa Indonesia memiliki potensi kekayaan gas bumi yang besar. Namun, sebagai salah satu sumber daya alam yang tidak dapat diperbaharui, dengan jumlah yang terbatas, dan mempengaruhi hajat hidup orang banyak, maka gas bumi digolongkan kepada komoditi strategis.

Dalam pengaturan tata kelola gas bumi, khususnya mengenai sektor hilir, masih menjadi persoalan karena inkonsistensi peraturan perundang-undangan terkait dengan pemaknaan skema pemanfaatan terbuka. UU Migas secara umum menganut sistem common carriage, namun dalam peraturan pelaksananya condong kepada sistem open access, yang dinilai sarat nilai-nilai liberalisme di dalamnya. Open access sendiri secara otomatis akan diikuti dengan penerapan unbundling,

1 Anonim, Gas Alam, diakses melalui http://www.indonesia-investments.com/id/bisnis/komoditas/gas-alam/ item184.pada tanggal 6 Februari 2016, pukul 23.11 WIB.

2 Anonim, Cadangan Gas Indonesia, Terbesar Ke-14 di Dunia, diakses melalui http://katadata.co.id/ infografik/2014/07/02/cadangan-gas-indonesia-terbesar-ke-14-dunia\#sthash.Q8gOyf67.dpbs, pada tanggal 6 Februari 2016, pukul 6.04 WIB. 
khususnya di sektor hilir. Open access terbukti telah memperpanjang mata rantai usaha, sehingga berujung pada kenaikan harga jual gas bumi, yang menurut para kalangan akademisi tidak mencerminkan tujuan akhir dari konstitusi yaitu "untuk sebesar-besarnya kemakmuran rakyat". Selain itu, dari pengalaman Negara-negara yang menganut open access secara umum terdapat harga gas bumi yang lebih tinggi dari pada Negara yang tidak menerapkannya.

\section{RUMUSAN MASALAH}

Berdasarkan latar belakang di atas maka dapat dirumuskan beberapa rumusan masalah yaitu:

1. Bagaimanakah inkonsistensi pengaturan open access dan unbundling dalam peraturan perundang-undangan terkait tata kelola gas bumi di Indonesia?

2. Bagaimanakah konsep open access dan unbundling dalam tata kelola gas bumi ditinjau dari perspektif ekonomi kerakyatan?

\section{METODE PENELITIAN}

Penelitian ini merupakan penelitian hukum yuridis normatif yaitu penelitian hukum yang mengacu kepada kaidah atau norma yang terdapat dalam peraturan perundang-undangan. ${ }^{3}$ Sedangkan metode pendekatan yang digunakan adalah pendekatan perundang-undangan (statute approach). Jenis dan sumber data yang Penulis gunakan dalam penelitian ini adalah berupa data sekunder yang terdiri dari: pertama, bahan hukum primer, yaitu berupa bahan-bahan yang memiliki kekuatan mengikat, seperti peraturan perundang-undangan dan Putusan Mahkamah Konstitusi yang terkait. Kedua, bahan hukum sekunder, berupa bahan yang menjelaskan bahan hukum primer dan isinya tidak mengikat. Ketiga, bahan hukum tersier. Metode pengumpulan data adalah dengan Studi Dokumen. Sedangkan metode pengelolaan dan analisis bahan hukum dilakukan dengan cara editing, yaitu pengelolaan bahan hukum dengan cara menyusun kembali, meneliti, dan memeriksa bahan-bahan hukum yang telah diperoleh agar dapat tersusun secara sistematis. ${ }^{4}$

\section{KERANGKA TEORI}

\section{Open Access}

Open access secara historis berasal dari konsep pengangkutan gas bumi melalui pipa yang bertitik tolak pada "prinsip pemanfaatan bersama" fasilitas pengangkutan. Di dalam praktik internasional terdapat 4 skema pemanfaatan bersama, yaitu: ${ }^{5}$

a. Negotiated Access, suatu Badan usaha secara sukarela membagi pemanfaatan fasilitas dengan pihak lain melalui skema business to business berdasarkan perjanjian, tanpa ada regulasi yang mewajibkan pemilik fasilitas untuk membagi pemanfaatan dengan badan usaha lain. Jadi, dalam skema ini pemilik fasilitas mempunyai hak untuk memutuskan akan membagi/tidak pemanfaatan fasiltas miliknya kepada pihak lain dan tidak ada sanksi jika tidak melakukannya.

b. Third-party Access, dimana terdapat regulasi yang mewajibkan badan usaha pemilik fasilitas pengangkutan untuk membagi pemanfaatan bersama pihak lain; apabila masih ada kapasitas lebih yang dapat digunakan oleh pihak lain. Dengan kata lain, pemanfaatan bersama dibatasi oleh besarnya kapasitas fasilitas yang masih tersedia. Pemanfaatan

3 Sudikno Mertokusumo, 2001, Penelitian Hukum Suatu Pengantar, cet. II, Yogyakarta, Liberty, hlm. 29.

4 Johnny Ibrahim, 2007, Teori dan Metode Penelitian Hukum Normatif, Surabaya, Bayumedia, hlm. 300.

$5 \quad$ Materi Seminar Nasional "Menilai Keselarasan Antara Penerapan Open Access dan Unbundling Dalam Pengelolaan Gas Bumi Dengan Kebijakan Energi Nasional” oleh Pusat Studi Energi Universitas Gadjah Mada, pada tanggal 25 Agustus 2014, dengan tema "Pemanfaatan Gas Alam Menuju Kedaulatan Energi Indonesia: Tinjauan Multidisiplin dari Aspek Industri, Aspek Hukum, dan Aspek Ekonomi”. Diakses dari http://pse.ugm. ac.id/?page id=904 pada tanggal 7 Februari 2016, pukul 12.48 WIB. 
bersama bisa dilakukan jika sudah ada persetujuan dari pemilik fasilitas, pengguna dan regulator.

c. Common Carriage, dimana fasilitas pipa diwajibkan untuk dapat diakses seluruh pengguna tanpa batasan kapasitas. Dasar penggunaan melalui penyesuaian alokasi kapasitas pengguna,jadi prinsip dalah semua harus dapat menggunakan melalui penyesuaian kapasitas. Dengan kata lain, siapapun pengguna yang memenuhi syarat berhak mendapatkan akses untuk menggunakan fasilitas dengan konsekuensi mengurangi alokasi penggunaan fasilitas oleh pihak lain.

d. Open access, dimana fasilitas yang dibangun oleh suatu Badan Usaha dimanfatkan bersama dengan prinsip first come first serve. Regulasi mewajibkan pemilik fasilitas pengangkutan membagi pemanfaatan fasilitas selama masih dalam batas maksimum kapasitas. Skema ini sekaligus memisahkan antara pengelola fasilitas (Transponder) dan pengguna (Shipper).

\section{Unbundling}

Pada dasarnya, konsep open access selalu diikuti dengan keberlakuan unbundling. Konsep dasar dari unbundling ialah "skema pemisahan (spin off)", dalam hal ini antara kegiatan niaga (suplai) dan kegiatan infrastruktur (pengangkutan) gas bumi (non horizontal integration). Walaupun tidak dapat dikatakan juga bahwa unbundling adalah spin off, namun secara umum, konsepnya adalah pemisahan perusahaan. Tujuan dari spin off adalah agar tercapai transparansi, independensi, dan persaingan yang sehat. Dalam praktik pengelolaan gas bumi di Eropa dikenal 4 bentuk Unbundling, yaitu: ${ }^{6}$

a. Account unbundling, dimana keuangan dari kegiatan infrastruktur harus terpisah dari keuangan kegiatan suplai.

b. Functional unbundling, dimana keuangan maupun manajemen kegiatan infrastruktur harus dipisah dari kegiatan suplai.

c. Legal Unbundling, dimana kegiatan infrastruktur dan kegiatan suplai masing-masing berada dibawah bendera entitas legal yang berbeda. Namun, masih dapat berada dalam struktur perusahaan induk, sehingga perusahaan induk masih memiliki kepemilikan.

d. Ownership Unbundling, dimana kegiatan infrastruktur dan kegiatan suplai harus dilakukan dan dimiliki oleh entitas yang berbeda dan masing-masing entitas ini tidak boleh mempunyai kepemilikan di dalam sekaligus kedua aktivitas tersebut.

Seperti yang telah diuraikan di atas, bahwa konsep dasar unbundling merupakan skema pemisahan (spin off). Konstruksi hukum spin off, meskipun sudah lama dikenal sebagai salah satu mekanisme restrukturisasi perusahaan, namun baru mendaptkan pengakuan secara legislasi dalam UU No. 40 Tahun 2007 tentang Perseroan terbatas (selanjutnya disebut UU PT). ${ }^{7}$

Pada Pasal 1 angka 12 UU PT, spin off disebut dengan "Pemisahan". Di dalam pasal tersebut, Pemisahan didefinisikan sebagai berikut: "Pemisahan adalah perbuatan hukum yang dilakukan oleh Perseroan untuk memisahkan usaha yang mengakibatkan seluruh aktiva dan pasiva Perseroan beralih karena hukum kepada 2 (dua) Perseroan atau lebih atau sebagian aktiva dan pasiva Perseroan beralih karena hukum kepada 1 (satu) Perseroan atau lebih.

Selanjutnya dalam Pasal 135 UU PT, Pemisahan dibedakan menjadi 2 macam, yaitu Pemisahan murni dan Pemisahan tidak murni. Pemisahan murni mengakibatkan seluruh aktiva dan pasiva Perseroan beralih karena hukum kepada 2 (dua) Perseoan lain atau lebih

$6 \quad$ Ibid.

7 Mulhadi, 2010, Hukum Perseroan dan Bentuk-Bentuk Badan Usaha Di Indonesia, Bogor, Ghalia Indonesia, hlm. 28 . 
yang menerima peralihan dan Perseroan yang melakukan pemisahan usaha tersebut berakhir karena hukum. Sementara, Pemisahan tidak murni mengakibatkan sebagian aktiva dan pasiva Perseroan beralih karena kepada 1 (satu) Perseroan lain atau lebih yang menerima peralihan, dan Perseroan yang melakukan pemisahan tersebut tetap ada. ${ }^{8}$

\section{PEMBAHASAN HASIL PENELITIAN DAN ANALISIS}

\section{Inkonsistensi Pengaturan Open Access dan Unbundling dalam Peraturan Perundang- undangan terkait Tata Kelola Gas Bumi di Indonesia}

Pengaturan tentang tata kelola gas bumi secara umum diatur dalam UU Migas, dan sejumlah aturan pelaksana terkait yang berada di bawahnya. Terkait dengan open access, perlu digarisbawahi bahwa tidak ada satu frase pun di dalam UU Migas yang menyebutkan tentang mekanisme open access. UU Migas, khususnya dalam Pasal 8 ayat (3) hanya mengatur tentang "pemanfaatan terbuka". Adapun bunyi Pasal 8 ayat (3) tersebut adalah: "Kegiatan usaha Pengangkutan Gas Bumi melalui pipa yang menyangkut kepentingan umum, pengusahaannya diatur agar pemanfaatannya terbuka bagi semua pemakai".

Dalam praktik Internasional, pemanfaatan terbuka ada 4 (empat) bentuk. Sebagaimana yang telah dijelaskan pada bagian sebelumnya, bahwa keempat bentuk kemanfaatan terbuka tersebut adalah: pertama, Negotiated Access, suatu Badan usaha secara sukarela membagi pemanfaatan fasilitas dengan pihak lain melalui skema business to business berdasarkan perjanjian, tanpa ada regulasi yang mewajibkan pemilik fasilitas untuk membagi pemanfaatan dengan badan usaha lain. Kedua, Third-party Access, dimana terdapat regulasi yang mewajibkan badan usaha pemilik fasilitas pengangkutan untuk membagi pemanfaatan bersama pihak lain; apabila masih ada kapasitas lebih yang dapat digunakan oleh pihak lain.

Ketiga, Common Carriage, dimana fasilitas pipa diwajibkan untuk dapat diakses seluruh pengguna tanpa batasan kapasitas. Keempat, Open access, dimana fasilitas yang dibangun oleh suatu Badan Usaha dimanfatkan bersama dengan prinsip first come first serve. Regulasi mewajibkan pemilik fasilitas pengangkutan membagi pemanfaatan fasilitas selama masih dalam batas maksimum kapasitas. Skema ini sekaligus memisahkan antara pengelola fasilitas (Transponder) dan pengguna (Shipper).

Jika ketentuan Pasal 8 ayat (3) UU Migas tersebut dihubungkan dengan dalam dihubung keempat bentuk pemanfaatan terbuka tersebut, maka dapat disimpulkan bahwa Pasal 8 ayat (3) UU Migas condong pada jenis Common Carriage, dimana fasilitas pipa diwajibkan untuk dapat diakses seluruh pengguna tanpa batasan kapasitas.

Maka, bagaimanakah dengan peraturan pelaksana dari UU Migas mengenai hal ini? Ada sejumlah peraturan perundang-undangan yang mengatur lebih lanjut ketentuan mengenai skema pemanfaatan terbuka ini. Diantaranya adalah:

a. Peraturan Pemerintah Nomor 67 Tahun 2002 tentang Badan Pengatur Penyediaan dan Pendistribusian Bahan Bakar Minyak dan Kegiatan Usaha Pengangkutan Gas Bumi melalui Pipa. Ketentuan dalam Penjelasan Umum PP ini berbunyi “......kegiatan pengangkutan gas bumi agar pemanfaatannya terbuka bagi semua pemakai”. Jika dianalis, maka dapat disimpulkan bahwa PP ini menganut skema pemanfaatan terbuka Common Carriage.

b. Peraturan Pemerintah Nomor 36 Tahun 2004 tentang Kegiatan Usaha Hilir Minyak dan Gas Bumi. Terdapat di Penjelasan di Penjelasan Pasal 31 ayat (1) berbunyi “.... terhadap fasilitas Pengangkutan Melalui Pipa yang mempunyai kapasitas lebih dapat dimanfaatkan pihak lain tanpa mengganggu kegiatan operasional pemilik... pihak lain yang akan memanfaatkan fasilitas harus mempertimbangkan kepentingan keekonomian pemilik fasilitas antara lain tingkat pengembalian investasi (rate of return)". Kata "dapat

8 CST Kansil dan Christine ST. Kansil,2009, Seluk Beluk Perseroan Terbatas Menurut Undang-Undang No. 40 Tahun 2007, Jakarta, Rineka Cipta, hlm. 93. 
dimanfaatkan pihak lain" menyimpulkan bahwa konsep skema pemanfaatan terbuka yang dianut oleh PP ini adalah Third-party Access

c. Keputusan Menteri ESDM Nomor $1321 \mathrm{~K} / 20 / \mathrm{MEM} / 2005$ dengan tegas menggunakan skema pemanfaatan open access.

d. Peraturan BPH Migas Nomor 11 Tahun 2007 dengan tegas menggunakan skema pemanfaatan open access.

e. Peraturan BPH Migas Nomor 15 Tahun 2008 dengan tegas menggunakan skema pemanfaatan open access.

f. Peraturan Menteri ESDM Nomor 19 Tahun 2009 tentang Kegiatan Usaha Gas Bumi melalui Pipa menggunakan skema pemanfaatan terbuka dengan bentuk open access, kecuali dapat berbentuk dedicated hilir, (pemakaian sendiri) untuk Badan Usaha yang tidak dapat memanfaatkan Pipa Transmisi dan/atau Pipa Distribusi secara bersama disuatu Wilayah Niaga Tertentu akibat kendala teknis dan ekonomis. Hal ini diterangkan secara tegas dalam Pasal 9 dan Pasal 10 ayat (1) dan (2).

Dari pemaparan tersebut terlihat bahwa peraturan pelaksana yang ada, masih berbedabeda dalam menafsirkan skema pemanfaatan terbuka yang dianut oleh Pasal 8 ayat (3) UU Migas. Kerancuan dalam pemaknaan ini tentu membawa pengaruh yang signifikan dalam pelaksanaan tata kelola gas bumi di Indonesia.

Pemaknaan pemanfaatan terbuka dengan skema open access seperti yang dimaksud dalam Permen Nomor 19 Tahun 2009 sebagai aturan teknis membawa implikasi penerapan sistem unbundling sebagai faktor pengikutnya. Jika kita mencermati UU Migas, khususnya Pasal 23 ayat (3) yang berbunyi: "Setiap Badan Usaha dapat diberi lebih dari 1 (satu) Izin Usaha sepanjang tidak bertentangan dengan ketentuan peraturan perundang-undangan yang berlaku." Ini artinya, UU Migas bersifat tidak imperatif atau bersifat fakultatif pilihan dalam penerapan unbundling. Namun, hal ini sangat berbeda dengan pengaturan yang terdapat dalam Permen Nomor 19 Tahun 2009 yang terdapat dalam pasal-pasal yang terdapat pada "Bagian Kedua" tentang Kegiatan Usaha Pengankutan Gas Bumi melalui Pipa, yang mengatur unbundling sebagai suatu keharusan terhadap seluruh badan usaha, yang bergerak di sektor hilir.

Sebagaimana yang telah dijelaskan pada bagian sebelumnya, bahwa erdapat 4 (empat) macam sistem unbundling, yaitu: Account unbundling, Functional unbundling, Legal Unbundling, dan Ownership Unbundling,

Dari keempat tipe Unbundling tersebut, Indonesia menggunakan tipe keempat, yaitu Ownership Unbundling ${ }^{9}$, dimana kegiatan infrastruktur dan kegiatan suplai harus dilakukan dan dimiliki oleh entitas yang berbeda dan masing-masing entitas ini tidak boleh mempunyai kepemilikan di dalam sekaligus kedua aktivitas tersebut.

Dengan lahirnya UU Migas pada tahun 2001, maka telah terjadi restrukturisasi fundamental pada usaha pertambangan migas. UU Migas telah mencabut Undang Undang Nomor 44 Prp Tahun 1960 dan UndangUndang Nomor 8 Tahun 1971. Restrukturisasi tersebut telah mengubah struktur industri energi yang semula terintegrasi vertikal (didominasi/ dimonopoli oleh perusahaan milik Negara) ke struktur yang terpecah-pecah (unbundled) dengan menumbuhkan kompetisi, membentuk BPH Migas, menata ulang fungsi-fungsi pemerintahan dan membentuk peraturan perundang-undangan yang mendukung pelaksanaan restrukturisasi tersebut. ${ }^{10}$

$9 \quad$ Ibid.

10 Hanan Nugroho, "Deregulasi Setengah Hati: Tinjauan terhadap Restrukturisasi Energi di Indonesia" (Makalah disampaikan pada seminar Akademik Tahunan Ekonomi I, Pasca Sarjana Ekonomi Universitas Indonesia \& Ikatan Sarjana Ekonomi Indonesia, Jakarta, 8-9 Desember 2004), hlm. 1 
Hal tersebut dapat dilihat pada tujuan penyelenggaraan kegiatan usaha Migas yang diatur dalam UU Migas, antara lain:

a. Menjamin efektivitas pelaksanaan dan pengendalian kegiatan usaha eksplorasi dan eksploitasi secara berdaya guna, berhasil guna, serta berdaya saing tinggi dan berkelanjutan atas Minyak dan Gas Bumi milik Negara yang strategis dan tidak terbarukan melalui mekanisme yang terbuka dan transparan.

b. Menjamin efektivitas pelaksanaan dan pengendalian usaha Pengolahan, Pengangkutan, Penyimpanan dan Niaga secara akuntabel yang diselenggarakan melalui mekanisme persaingan usaha yang wajar, sehat, dan transparan. ${ }^{11}$

Dengan berpedoman pada tujuan tersebut, maka pengusahaan Migas dipecah menjadi 2 (dua), yaitu: pertama, Kegiatan Usaha Hulu yang mencakup eksplorasi dan eksploitasi, dan kedua, Kegiatan Usaha Hilir yang mencakup pengolahan, pengangkutan, penyimpanan, dan niaga. ${ }^{12}$ Pemisahan (unbundling) ini bertujuan untuk menghindari integrasi vertikal dari hulu sampai hilir. Berdasarkan hal tersebut, maka Badan Usaha yang melakukan pengusahaan migas di sektor hulu dilarang melakukan pengusahaan migas di sektor hilir, dan sebaliknya Badan Usaha yang melakukan pengusahaan migas di sektor hilir dilarang melakukan pengusahaan migas di sektor hulu. ${ }^{13}$

Pemisahan (unbundling) dalam pengusahaan gas bumi melalui pipa dalam konteks UU Migas merupakan salah satu kegiatan usaha hilir perusahaan. Pemisahan (unbundling) ini secara tegas diatur dalam UU Migas yang terbagi atas kegiatan pengangkutan gas bumi melalui pipa transmisi dan distribusi, ${ }^{14}$ serta niaga gas bumi melalui pipa. ${ }^{15}$ Selanjutnya UU Migas mengatur bahwa Badan Usaha pemegang Izin Usaha Pengangkutan Gas Bumi melalui pipa transmisi dan distribusi hanya dapat melakukan kegiatan ushanya pada ruas Pengangkutan tertentu, ${ }^{16}$ dan Badan Usaha pemegang Izin Usaha Niaga Gas Bumi melalui pipa hanya dapat melakukan melakukan kegiatan usahanya pada Wilayah Niaga Tertentu. ${ }^{17}$

Walaupun UU Migas mensyaratkan terciptanya persaingan yang sehat dalam melakukan pengusahaan gas bumi melalui pipa, namun demikian terdapat karakteristik alamiah pada kegiatan pengangkutan gas bumi melalui pipa transmisi dan pipa distribusi. Sebagaimana disampaikan oleh Robert Priddle selaku Executive Director of the International Energy Agency (IEA) dalam Jurnal pada tahun 1998, bahwa:

"Gas can be bought and sold like any other goods, but its transportation in most cases are natural monopoly; it is generally inefficient to build competing networks - particularly for local distribution - because of economic of scale, although some aspects of operating the networks may not be monopolistic, e.g. matering. Thus, the supply of gas to end users will in most cases always involve an element of monopoly - even in a competitive market. ${ }^{18}$

11 Indonesia, Undang Undang Nomor 22 Tahun 2001 tentang Minyak dan Gas Bumi (LN Tahun 2001 Nomor 136; TLN Nomor 4152), Pasal 3 huruf a dan hurufb.

12 Ibid., Pasal 5 angka 1 dan angka 2

13 Ibid., Pasal 10 ayat (1) dan ayat (2)

14 Ibid., Pasal 1, angka 12

15 Ibid., Pasal 1, angka 14

16 Ibid., Pasal 27 ayat (2)

17 Ibid., Pasal 27 ayat (3)

18 Henry Yulius Winnes Hutagaol, 2012, Monopoli Pengusahaan Gas Bumi Melalui Pipa dalam Perspektif Persaingan Usaha (Tesis) Jakarta, Fakultas Hukum Universitas Indonesia, hlm. 17. 
Priddle berpendapat bahwa komoditas gas bumi pada prinsipnya dapat diperdagangkan layaknya komoditas dagang lainnya, namun demikian terdapat sifat monopoli alamiah dalam pengangkutannya melalui pipa transmisi dan/atau pipa distribusi. Pada prinsipnya adalah tidak menguntungkan untuk membangun jaringan pipa yang berdaya saing, khususnya untuk jaringan pipa distribusi yang bersifat lokal mengingat skala bisnisnya yang kecil, walaupun dalam beberapa aspek pengusahaan jaringan pipa distribusi tersebut ada yang tidak bersifat monopoli, seperti alat ukur untuk mengetahui pipa kepada pengguna akahir selalu terkandung di dalamnya unsur monopoli, sekalipun dalam suatu pasar yang bersaing.

Maka, dari pemaparan tersebut terlihat bahwa terdapat tabrakan ketentuan antara peraturan perundang-undangan yang mengatur tata kelola migas. Salah satu yang paling mendapat sorotan adalah ketentuan Permen Nomor 19 Tahun 2009 yang secara substansi bertabrakan dengan ketentuan yang terdapat dalam UU Migas sendiri.

\section{Konsep Open Access dan Unbundling dalam Tata Kelola Gas Alam Ditinjau dari Perspektif Ekonomi Kerakyatan}

Negara Indonesia dibentuk dengan tujuan melindungi segenap bangsa Indonesia dan seluruh tumpah darah Indonesia, memajukan kesejahteraan umum, mencerdaskan kehidupan bangsa, dan ikut melaksanakan ketertiban dunia yang berdasarkan kemerdekaan, perdamaian abadi, dan keadilan sosial. Menurut Sri Soemantri, dengan demikian, pada dasarnya Indonesia sejak awal kemerdekaan telah menganut konsep Negara Kesejahteraan. ${ }^{19}$

Selanjutnya, Moh. Mahfud MD menyatakan bahwa dapat disimpulkan bahwa Negara hukum Indonesia adalah Negara hukum yang materiel (Welfare State), karena di dalam UUD 1945 ditegaskan tentang kewajiban pemerintah yang melekat pada Negara hukum meteriel yaitu memajukan kesejahteraan umum, mencerdaskan kehidupan bangsa, dan mewujudkan keadilan sosial bagi seluruh rakyat. ${ }^{20}$

Gas bumi sebagai komoditi strategis di dalam Undang-Undang Dasar Republik Indonesia Tahun 1945 (Selanjutnya disebut UUD 1945) diatur dalam Bab IV tentang Perekonomian Nasional dan Kesejahteraan Sosial, khususnya pada Pasal 33 ayat (2) dan (3). Pasal 33 UUD 1945 ayat (2) berbunyi: "cabang-cabang produksi yang penting bagi Negara dan yang menguasai hajat hidup orang banyak dikuasai oleh Negara." Sedangkan ayat (3) berbunyi: "bumi, air, dan kekayaan alam yang terkandung di dalamnya dikuasai oleh Negara dan dipergunakan untuk sebesar-besarnya kemakmuran rakyat."

Penafsiran tentang konsep hak menguasai Negara yang terhadap Pasal 33 UUD 1945 dapat dicermati dalam beberapa putusan Mahkamah Konstitusi terkait kasus-kasus pengujian undang-undang yang berhubungan dengan Sumber Daya Alam. ${ }^{21}$ Secara garis besar MK menyatakan bahwa pengertian "dikuasai oleh negara" haruslah diartikan mencakup makna penguasaan oleh negara dalam arti luas yang bersumber dan diturunkan dari konsepsi kedaulatan rakyat Indonesia atas sumber kekayaan "bumi, air dan kekayaan alam yang terkandung di dalamnya" termasuk pula didalamnya pengertian kepemilikan publik oleh kolektivitas rakyat atas sumber-sumber kekayaan dimaksud. Rakyat secara kolektif itu dikonstruksikan oleh UUD 1945 memberikan mandat kepada negara untuk mengadakan 5

19 Djauhari, 2008, Politik Hukum Negara Kesejahteraan Indonesia (Studi tentang Kebijakan Regulasi dana Institusionalisasi Gagasan Kesejahteraan Sosial Ekonomi Masyarakat Nelayan di Jawa Tengah), Semarang, Unissula Press, hlm. 1. Baca juga Darji Darmodiharjo dan Shidarta, 2006, Pokok-Pokok Filsafat Hukum Indonesia, Jakarta, PT. Gramedia Pustaka Utama, hlm. 178.

20 Moh. Mahfud MD, 2000, Demokrasi dan Konstitusi di Indonesia, Jakarta, Rineka Cipta, hlm. 132-133.

21 Lihat J. Ronald Mawuntu, Konsep Penguasaan Negara berdasarkan Pasal 33 UUD 1945 dan Putusan Mahkamah Konstitusi, Jurnal Unstrad, Vol. XX/No.3/April-Juni/2012,diakses melalui http://repo.unsrat. ac.id/273/1/KONSEP_PENGUASAAN_NEGARA_BERDASARKAN_PASAL_33_UUD_1945_DAN PUTUSAN_MAHKAMAH_KONSTITUSI.pdf, pada tanggal 7 Februari 2016, pukul 8.00 WIB. 
(lima) macam kewenangan, yaitu: pertama, kebijakan (beleid), kedua, tindakan pengurusan (bestuurdaad), ketiga, pengaturan (regelendaad), keempat, pengelolaan (beheersdaad), dan kelima, pengawasan (toezichthoudensdaad) untuk tujuan sebesar-besarnya kemakmuran rakyat. ${ }^{22}$ Dan perlu dicatat, bahwa kelima ketentuan tersebut merupakan satu kesatuan yang tidak dapat dipisahkan satu sama lainnya.

Dari penafsiran tersebut, dapat diambil kesimpulan bahwa pada dasarnya konsep penguasaan Negara yang terdapat dalam Pasal 33 UUD 1945 terdiri dari 2 (dua) hal pokok, yaitu: pertama, pengelolaan SDA dikuasai oleh Negara melalui 5 (lima) macam kewenangan tadi, dan kedua, hasil pengelolaan SDA tersebut dipergunakan sebesar-besarnya untuk kemakmuran rakyat. Jika kita hubungkan dengan potensi gas alam yang terdapat di bumi Indonesia, maka kewajiban Pemerintah untuk menjamin ketersediaan, kelancaran distribusi, dan keterjangkauan harga bagi rakyat Indonesia, dengan menggunakan 5 (lima) kewenangan seperti yang disebutkan di atas, yang berujung pada kemakmuran rakyat seutuhnya. ${ }^{23}$

Pengaturan tentang gas bumi pada level undang-undang diatur dalam Undang-Undang Nomor 22 Tahun 2001 tentang Minyak dan Gas Bumi (selanjutnya disebut UU Migas). Secara historis, kelahiran UU Migas dipengaruhi oleh persyaratan yang termuat dalam Letter of Intent (LOI), ketika tahun 1997 Indonesia dalam keadaan krisis moneter dan harus mendapatkan pinjaman dari Bank Dunia dan IMF. LOI bersandar pada prinsip kapitalisme yang menginginkan adanya liberalisasi dalam pengelolaan perekonomian nasional. Implementasinya melalui liberalisasi lembaga keuangan, penanaman modal, termasuk di dalamnya ketentuan tentang Migas. Dampaknya adalah keharusan peraturan perundang-undangan dalam bidang perekonomian disesuaikan dengan persyaratan LOI, sehingga ketentuan Pasal 33 UUD 1945 hanya formalitas, tetapi tidak menjadi ruh dalam substansi yang terdapat dalam pasal-pasal peraturan perundang-undangan tersebut. ${ }^{24}$

Betul saja, dalam perjalanannya, UU Migas ternyata terbukti sarat kepentingan ekonomi yang bertentangan dengan konstitusi. Sejumlah Pasal yang terdapat di dalam UU Migas telah dibatalkan oleh Mahkamah Konstitusi karena dinilai bertentangan dengan konstitusi, seperti ketentuan mengenai eksistensi BP Migas, ketentuan Pasal 22 ayat (1) tentang kewajiban paling banyak penyerahan $25 \%$ dari hasil produksi, hingga terkait ketentuan Pasal 28 ayat (2) tentang penyerahan harga migas kepada mekanisme pasar. Namun ternyata, pasca dibatalkannnya sejumlah Pasal di UU Migas tersebut oleh MK, beberapa masalah terkait tata kelola migas ini pun terus bergulir. Salah satunya adalah mengenai masalah penerapan sistem Open Access dan Unbundling yang sarat dengan nilai liberalisasi. ${ }^{25}$

Sebenarnya ketentuan mengenai Open Access dan Unbundling dalam UU Migas sudah pernah di-judicial review-kan ke Mahkamah Konstitusi, namun ketentuan tersebut dinilai tidak bertentangan dengan konstitusi. Namun uniknya, dalam Putusan MK Nomor 001-021-022/PUU-I/2003 membatalkan sistem unbundling dalam UU Ketenagalistrikan karena Unbundling dinilai mereduksi makna "dikuasai oleh Negara untuk cabang cabang produksi yang penting yang menguasai hajat hidup orang banyak" karena merupakan suatu pembatasan dan penyempitan kewenangan atau kekuasaan Negara dalam menguasai listrik sebagai cabang produksi penting Negara. Selain itu, konsep unbundling ini diyakini hanya

22 Lihat Putusan Mahkamah Konstitusi Nomor 36/PUU-X/2012, diakses melalui http://www.mahkamahkonstitusi. go.id/public/content/persidangan/putusan/putusan_sidang_36\%20PUU\%202012\%20migas\%20-\%20 telah\%20baca\%2013\%20Nov\%202012.pdf, pada tanggal 6 Februari 2016, pukul 7.35 WIB. 8

23 Baca Muhammad Erwin, 2012, Filsafat Hukum Refleksi Kritis terhadap Hukum, Jakarta, Rawali Press, hlm. 285.

24 Candra Irawan, 2013, Dasar-Dasar Pemikiran Hukum Ekonomi Indonesia, Bandung, Mandar Maju, hlm. 68.

25 Anonim, Open Access dan Unbundling Bentuk Liberalisasi Bisnis Gas, diakses melalui http://www.gatra.com/ ekonomi-1/47894-open-access-dan-unbundling-bentuk-liberalisasi-bisnis-gas.html pada tanggal 6 Februari 2016 pukul 8.09 WIB 
memicu para pihak-pihak swasta yang hanya ingin memanfaatkan usaha listrik di bidang tertentu (Free Rider).

Di akhir putusannya dinyatakan secara gamblang bahwa konsep unbundling yang menajadi jantung dalam UU Ketengalistrikan ini, UU No 20 Tahun 2002, menjadi sebuah penyakit besar yang melawan konstitusi dan oleh karena itu, dalam rangka penyelamatan, perlindungan dan pengembangan lebih lanjut BUMN atau PLN sebagai aset Negara dan bangsa agar lebih sehat yang selama ini telah berjasa memberikan pelayanan kelistrikan, mahkamah memutuskan bahwa konsep Unbundling bertentangan dengan dasar Negara yang tertulis dalam pasal 33 UUD 1945.

Sedangkan terkait dengan judicial review UU Migas terkait dengan Open Access dan Unbundling, yaitu dalam Putusan MK Nomor 002/PUU-I/2003 dan Putusan MK Nomor 36/ PUU-X/2012, MK memutuskan hal yang sama dengan pertimbangan hukum sebagai berikut: ${ }^{26}$

"Menimbang bahwa para Pemohon mendalilkan Pasal 10 dan Pasal 13 UU Migas bertentangan dengan Pasal 33 UUD 1945 dengan alasan yang pada pokoknya bahwa norma dalam pasal-pasal tersebut mengurangi kedaulatan negara atas penguasaan sumber daya alam (Migas) karena pemecahan organisasi secara vertikal dan horizontal (unbundling) akan menciptakan manajemen baru yang akan menentukan cost dan profit masing-masing. Terhadap dalil para Pemohon tersebut, Mahkamah dalam putusan Nomor 002/PUU-I/2003, tanggal 21 Desember 2004 telah mempertimbangan mengenai pemisahan (unbundling) kegiatan usaha, yaitu "... ketentuan pasal dimaksud harus ditafsirkan tidak berlaku terhadap badan usaha yang telah dimiliki oleh negara yang justru harus diberdayakan agar penguasaan negara menjadi semakin kuat. Pasal 61 yang termasuk dalam Ketentuan Peralihan harus ditafsirkan bahwa peralihan dimaksud terbatas pada status Pertamina untuk menjadi persero dan tidak menghapuskan keberadaannya sebagai Badan Usaha yang masih tetap melakukan kegiatan usaha hulu dan kegiatan usaha hilir, meskipun untuk usaha hilir dan hulu tersebut harus dilakukan oleh dua Badan Usaha "Pertamina Hulu" dan "Pertamina Hilir" yang keduanya tetap dikuasai oleh negara". Meskipun Pasal 13 UU Migas tidak termasuk dalam putusan Mahkamah tersebut, namun oleh karena substansinya sama dengan Pasal 10 UU Migas yaitu mengenai unbundling secara horizontal maka pertimbangan Mahkamah tersebut mutatis mutandis berlaku untuk pengujian Pasal 13 UU Migas. Oleh karena itu, menurut Mahkamah, pemisahan dalam kegiatan usaha hulu dan kegiatan usaha hilir dalam kegiatan minyak dan gas bumi sudah tepat. Adapun alasan kemungkinan hal itu akan menciptakan manajemen baru yang akan menentukan cost dan profit masing-masing, menurut Mahkamah, hal tersebut tidak terkait dengan permasalahan konstitusionalitas. Dengan demikian, dalil para Pemohon tersebut tidak beralasan menurut hukum"

Putusan MK yang tidak membatalkan ketentuan unbundling dari awal mengkhawatirkan akan banyak trader-trader yang menjadi free rider. Artinya, mereka melakukan trading, namun tidak mau membangun infrastruktur. Betul saja, menurut penelitian Pusat Studi Energi Universitas Gadjah Mada menemukan bahwa semenjak diberlakukannya sistem unbundling di Indonesia, infrastuktur tidak berkembang dengan baik. Selain itu, jika dilihat dari putusan MK tersebut yang pada intinya akan memberika prioritas kepada BUMN untuk tidak melaksanakan unbundling dan open access, namun kenyataan di lapangan tidak ada prioritas itu kepada BUMN, sehingga tetap dikenakan sistem unbundling.

Pemberlakuan unbundling ini bukan tanpa akibat. Unbundling pada kegiatan komoditas strategis seperti gas bumi menyebabkan usaha hilir gas bumi menjadi panjang mata rantainya, dan secara otomatis biaya akan semakin tinggi, dan ujungnya harga jual akan semakin tinggi, Putusan Mahkamah Konstitusi 36/PUU-X/2012 
sehingga ini tidak mencerminkan tujuan konstitusi, khususnya Pasal 33 untuk "sebesarbesarnya kemakmuran rakyat".

\section{KESIMPULAN DAN SARAN}

\section{Kesimpulan}

a. Telah terjadi inkonsistensi pengaturan Open Access dan Unbundling dalam peraturan perundang-undangan terkait tata kelola gas bumi di Indonesia. Hal ini terlihat dari pertentangan-pertentangan UU Migas dengan peraturan pelaksana yang berada di bawahnya terkait penafsiran skema pemanfaatan terbuka yang dianut oleh UU Migas, misalnya yang terdapat dalam Permen Nomor 19 Tahun 2009.

b. Konsep open access dan unbundling dalam tata kelola gas alam bertentang dengan tujuan dari perekonomian kerakyatan yang diusung dalam Pasal 33 ayat (2) dan (3) UUD 1945. Fakta menunjukkan bahwa penerapan open access unbundling ternyata membuat harga semakin naik, sehingga tidak mencerminkan tujuan dari amanat UUD 1945.

\section{Saran}

a. Perlu dilakukan antisipasi sesegera mungkin untuk membatalkan ketentuan pelaksana dari UU Migas tersebut, minimal setingkat Peraturan Presiden, yang membatalkan sistem unbundling tersebut.

b. Untuk revisi UU Migas yang sedang bejalan di DPR, perlu mempertimbangkan kejelasan mengenai skema pemanfaatan terbuka yang sesungguhnya akan diterapkan, sehingga tidak menimbulkan multitafsir dalam pemaknaan pemanfaatan terbuka dalam tata kelola migas, khususnya gas bumi.

\section{DAFTAR PUSTAKA}

Buku

Darmodiharjo, Darji dan Shidarta, 2006, Pokok-Pokok Filsafat Hukum Indonesia, Jakarta, PT. Gramedia Pustaka Utama

Djauhari, 2008, Politik Hukum Negara Kesejahteraan Indonesia (Studi tentang Kebijakan Regulasi dana Institusionalisasi Gagasan Kesejahteraan Sosial Ekonomi Masyarakat Nelayan di Jawa Tengah), Semarang, Unissula Press

Erwin, Muhammad, 2012, Filsafat Hukum Refleksi Kritis terhadap Hukum, Jakarta, Rawali Press Johnny Ibrahim, 2007, Teori dan Metode Penelitian Hukum Normatif, Surabaya, Bayumedia

Irawan, Candra, 2013, Dasar-Dasar Pemikiran Hukum Ekonomi Indonesia, Bandung, Mandar Maju

Kansil, CST dan Christine ST. Kansil, 2009, Seluk Beluk Perseroan Terbatas Menurut UndangUndang No. 40 Tahun 2007, Jakarta, Rineka Cipta

Mertokusumo, Sudikno, 2001, Penelitian Hukum Suatu Pengantar, cet. II, Yogyakarta, Liberty

Mahfud, Moh. MD, 2000, Demokrasi dan Konstitusi di Indonesia, Jakarta, Rineka Cipta

Mulhadi, 2010, Hukum Perseroan dan Bentuk-Bentuk Badan Usaha Di Indonesia, Bogor, Ghalia Indonesia

\section{Tulisan Ilmiah dan Jurnal}

Hanan Nugroho, "Deregulasi Setengah Hati: Tinjauan terhadap Restrukturisasi Energi di Indonesia" (Makalah disampaikan pada seminar Akademik Tahunan Ekonomi I, Pasca Sarjana Ekonomi Universitas Indonesia \& Ikatan Sarjana Ekonomi Indonesia, Jakarta, 8-9 Desember 2004) 
Henry Yulius Winnes Hutagaol, 2012, Monopoli Pengusahaan Gas Bumi Melalui Pipa dalam Perspektif Persaingan Usaha (Tesis) Jakarta, Fakultas Hukum Universitas Indonesia

\section{Peraturan Perundang-Undangan}

Indonesia, Undang Undang Nomor 22 Tahun 2001 tentang Minyak dan Gas Bumi (LN Tahun 2001 Nomor 136; TLN Nomor 4152), Pasal 3 huruf a dan huruf b

\section{Putusan-Putusan}

Putusan Mahkamah Konstitusi Nomor 36/PUU-X/2012

Putusan Mahkamah Konstitusi 36/PUU-X/2012

\section{Internet}

Anonim, Gas Alam, diakses melalui http:/www.indonesia-investments.com/id/bisnis/komoditas/ gas-alam/item184,pada tanggal 6 Februari 2016, pukul 23.11 WIB.

Anonim, Cadangan Gas Indonesia, Terbesar Ke-14 di Dunia, diakses melalui http://katadata.co.id/ infografik/2014/07/02/cadangan-gas-indonesia-terbesar-ke-14-dunia\#sthash.Q8gOyf67. dpbs, pada tanggal 6 Februari 2016, pukul 6.04 WIB.

Materi Seminar Nasional "Menilai Keselarasan Antara Penerapan Open Access dan Unbundling Dalam Pengelolaan Gas Bumi Dengan Kebijakan Energi Nasional” oleh Pusat Studi Energi Universitas Gadjah Mada, pada tanggal 25 Agustus 2014, dengan tema "Pemanfaatan Gas Alam Menuju Kedaulatan Energi Indonesia: Tinjauan Multidisiplin dari Aspek Industri, Aspek Hukum, dan Aspek Ekonomi”. Diakses dari http://pse.ugm.ac.id/?page_id=904 pada tanggal 7 Februari 2016, pukul 12.48 WIB.

Anonim, Open Access dan Unbundling Bentuk Liberalisasi Bisnis Gas, diakses melalui http:// www.gatra.com/ekonomi-1/47894-open-access-dan-unbundling-bentuk-liberalisasi-bisnisgas.html pada tanggal 6 Februari 2016 pukul 8.09 WIB

Ronald Mawuntu, Konsep Penguasaan Negara berdasarkan Pasal 33 UUD 1945 dan Putusan Mahkamah Konstitusi, Jurnal Unstrad, Vol. XX/No.3/April-Juni/2012,diakses melalui http://repo.unsrat.ac.id/273/1/KONSEP_PENGUASAAN_NEGARA_BERDASARKAN PASAL_33_UUD_1945_DAN_PUTUSAN_MAHKAMĀH_KONSTITUSI.pdf, pada tanggal 7 Februari 2016, pukul 8.00 WIB. 